\title{
İstenmeyen Öğrenci Davranışlarına Karşı Beden Eğitimi Öğretmenlerinin Tutumları İle Mesleki Tükenmişlik Düzeyleri Arasındaki Ílişkinin Analizi ${ }^{1}$
}

Ayşe Nur HANEDAR ${ }^{2}$
Mehmet ÖÇALAN ${ }^{3}$

\author{
${ }^{2}$ Kırıkkale Üniversitesi Sağlık Bilimleri Enstitüsü, KIRIKKALE \\ ${ }^{3}$ Kırıkkale Üniversitesi Spor Bilimleri Fakültesi, Beden Eğitimi ve Spor Eğitimi Bölümü, KIRIKKALE
}

Künye: Hanedar, A.N. ve Öçalan, M. (2018).İstenmeyen Öğrenci Davranışlarına Karşı Beden Eğitimi Öğretmenlerinin Tutumları İle Mesleki Tükenmişlik Düzeyleri Arasındaki İlişkinin Analizi. Gaziantep Üniversitesi Spor Bilimleri Dergisi 3(2): 46-60.

\section{Öz}

Araştırmanın amacı beden eğitimi öğretmenlerinin istenmeyen öğrenci davranışlarına karşı tutumları ile öğretmenlerin tükenmişlik düzeylerinin belirlenerek aralarındaki iliş̧inin ortaya çıkarılmasıdır. Araştırmanın çalışma grubunu 2017-2018 eğitim-öğretim yılında Ankara ili Yenimahalle ilçesi devlet ortaokulu ve liselerinde görev yapan 201 beden eğitimi öğretmeni oluşturmaktadır. Veri toplama araçları olarak, araştırmacı tarafından geliştirilen Kişisel Bilgi Formu ve İstenmeyen Davranışlara Karşı Tutum Ölçeği, Maslach ve Jackson (1981) tarafından geliştirilen Maslach Tükenmişlik Ölçeği kullanılmıştır. Sonuç olarak öğretmenlerin istenmeyen davranışlara karşı tutumları yaş ve bulundukları okuldaki görev yılı değişkenlerine göre anlamlı farklılık göstermiştir. Duygusal tükenmeyle ders yapılan alan, kişisel başarısızlıkla yaş, mesleki kıdem, eğitim durumu, ders yapılan alan ve sınıf mevcudu değişkenlerine göre anlamlı farklılık olduğu görülmüştür. İstenmeyen davranışlara karşı öğretmen tutumları ile kişisel başarısızlık alt boyutu arasındaki ilişki -0.25 olarak düşük ve negatif düzeyde bulunmuştur.

Anahtar Kelimeler: Beden Eğitimi Öğretmeni, İstenmeyen Öğrenci Davranışı, Tükenmişlik

\section{Orijinal Makale}

\section{Yayın Bilgileri}

Gönderi Tarihi: 13.05.2018

Kabul Tarihi: 29.05.2018

Yayın Tarihi: 20.06.2018

\section{Sorumlu Yazar}

e-mail: hanedarayse21@gmail.com

\section{The Analysis of the Correlation between the Attitudes of the Physical Education Teachers towards the Behaviors of Students and the Levels of Teachers'}

\section{Burnout}

\begin{abstract}
Purpose of study is to reveal relationships between physical education teacher's attitudes towards students' undesired behaviors and teachers' burnout levels. Investigation's sample is 201 physical education teachers working in state secondary and high schools in Yenimahalle, Ankara. Data was collected from demographic information form, Attitudes towards Unwanted Behaviors Scale $(\alpha=0.70)$ and Maclach Burnout Scale $(\alpha=0.71)$ developed by Maslach and Jackson (1981). Results show that there is significant differences between teachers' attitudes towards students' undesired behaviors and variables of teachers' ages and experiences at school and there is considerable difference between emotional exhaustion and teachers' age, professional seniority, educational level, course area and classroom size. Besides, there is negative correlation between teachers' attitudes towards students' undesired behaviors and personal failure as -0.25 .
\end{abstract}

\section{OriginalArticle}

Articlelnfo

Received: 13.05.2018

Accepted: 29.05.2018

Published:20.06.2018

Corresponding Author

e-mail: hanedarayse21@gmail.com

Keywords: Physical Education Teacher, Burnout, Student's Undesired Behavior,

\footnotetext{
${ }^{1}$ Bu çalışma 5. Uluslararası Spor Bilimleri Turizm ve Rekreasyon Öğrenci Kongresinde (07-09 Mayıs, Manisa) poster bildiri olarak sunulmuştur.
} 


\section{Giriş}

Sınıf yönetiminin iyi bir şekilde anlaşılması için sınıf kavramını açıklamak gereklidir. Sınıf, aynı gelişim döneminde olup benzer özelliklere sahip olmalarından dolayı bir araya gelen öğrencilerin, önceden belirlenen hedefleri gerçekleştirmesi için eğitimin yapıldığı ortamdır (Özyürek, 2013). Weston (1997)'a göre sınıf yönetimi, hedef ve ders görevlerinin önceden belirlenerek uygulanması ile başarı elde etmek için öğretmenin yetkilerini öğrencilerle demokratik bir şekilde paylaşmasıdır. Öğretmenlerin ders içinde en temel görevi belirlenen amaçlar doğrultusunda istendik davranışlar elde etmektir. Ancak öğretmen bu görevi yaparken, verdiği ödevleri kontrol etme, ders akışını bozan öğrenciler belirleme, dersi engelleyecek koşulları ortadan kaldırma gibi görevleri de üstlenir (Erden, 2008).Sınıf ortamını bozan ve ders akışını olumsuz yönde etkileyen unsurlardan biri istenmeyen davranışlardır. $\mathrm{Bu}$ davranışlar dersi zorlaştırır ve öğrenme ortamını olumsuz etkiler (Özdemir, 2011). Ancak bu davranışlardan bazıları dersin amaçlarına zarar vermeyebilir. Mesela derse fayda sağlıyorsa, izin almadan konuşmak olumsuz bir davranış olarak görülmemelidir (Dolye, 1986). Sınıf ortamındaki her önemsiz hatayı olumsuz davranış olarak değerlendiren öğretmenler, istemeyen davranışların daha çok meydana gelmesine neden olacaktır. Bu yüzden öğretmen, karşılaştığı davranışlara davranış bilimine hakim olarak tepki vermelidir (Okutan, 2015).

Öğretmen sınıf yönetimini etkili bir şekilde kullanıyor olsa bile bazı öğrenciler derse dikkatini veremez, bazıları ise kendi aralarında konuşabilirler. Bunlara karşı dersi dinlemeyen öğrencilerde olabilir. Bu gibi değişik öğrenci tiplerine sahip bir sınıfta tecrübeli öğretmen bile sınıf yönetiminde güçlük yaşayabilir (Korkmaz, 2011).

İstenmeyen davranışların sebepleri, öğrencilerin özellikleri ve aile ortamından kaynaklanabilir (Yalçınkaya ve Küçükkaragöz, 2006). Bu davranışların sebeplerine baktığımızda, olumsuz davranışlara eğimli olan öğrencileri görmekteyiz. Eğilimi olanlar; iletişim kurmakta zorluk çeken, sosyal becerileri yetersiz, okulu sevmeyen ve uyum sorunları yaşayan öğrencilerdir (Başar, 2001). Akademik başarısı düşük olan öğrencilerde sebeplerdendir. Bu öğrencilerin başarısını arttırmak önemlidir. Çünkü bunlar okulu sevmez ve kötü davranışlar sergiler (Cemaloğlu, 2015). Farklı bir sebep ise, sınıfta yarışma ortamı oluşturarak dengesiz öğrenme durumu oluşturmaktır. Bazı öğrenciler kazanırken bazıları kaybedecektir. Kaybeden öğrencilerde özgüvensizlik, suçluluk, geride kalma ve öfke gibi sonuçlar ortaya çıkar (Sarıtaş, 2000). 
Belirtildiği gibi beden eğitimi öğretmenlerinin karşılaştığı en önemli sorunlardan birinin istenmeyen davranışlar olduğu görülmektedir. Ders hedeflerinin gerçekleşmesinde bu davranışlar etkilidir. Bununla beraber öğretmenlerin etkili ders işleyebilmeleri için duygusal, fiziksel ve soysal yönlerden sağlıklı olmaları ve tükenmişlik yaşamamaları da önemlidir. İnsanların yapabileceği işler ile çevre beklentisi arasında oluşan dengesizlik strese neden olur. Stres yaşatan durumlarla baş etmede görülen olumsuzluklar ise tükenmişliği meydana getirir (Freudenberger, 1981). Tükenmişlik; duygusal tükenme, duyarsızlaşma ve düşük kişisel başarı olarak üç alt boyuttan oluşur (Maslach, ve ark., 2001). Duygusal tükenme, insanlara karşı empatinin azalması, iş stresinin artması ve başarı duygusunun azalması olarak tanımlanmıştır (Özmen, 2001). Duyarsızlaşma, kişinin işten dolayı iletişim kurduğu insanlara ve işine olan soğuk, düşük ve katı tutumlardan dolayı ortaya çıkar (Cordes ve Dougherty, 1993). Kişisel başarısızlık, başaramama korkusu, iş veriminin azalması, moralsizlik, düşük öz saygı ve problemlerle başa çıkamama duygusu gibi belirtileri ifade eder (Hock, 1988). Kişinin beklentileri gerçekleşmesi mümkün durumların üzerindeyse ve buna karşı kişi amaçlarına ulaşmakta ısrarcıysa sorunlar çıkacaktır. Bu durumda insanların kaynakları, yaşam enerjisi ve iş yapma yeteneği tükenecektir (Tümkaya, 1996).Tükenmişlik bazı kişileri bir bütün olarak etkiler, yüz yüze olan iletişimle kendi hayatlarındaki ilişkilerinde olumsuz sonuçlar ortaya çıkarır ve hayatlarına dair olumlu düşünceleri ortadan kaldııı (Özdemir, 2009).

İnsanlar tükenmişlikle baş ederken iki önemli strateji ön plana çıkar. Birincisi, stresle karşılaşıldığında pozitif olarak mücadele gerektiren doğrudan yapılan hareketlerdir. İkincisi ise, yaşanılan stresi kabullenip olumsuz durumları bitirmeyi amaçlayan hafifletmeye yönelik teknikler kullanmaktır (Kyriacou, 1987).

\section{Yöntem}

\section{Araştırma Deseni ve Modeli}

$\mathrm{Bu}$ araştırmada ortaokul ve liselerde çalışan beden eğitimi öğretmenlerinin istenmeyen davranışlara karşı gösterdikleri tutumlar ve mesleki tükenmişlik düzeylerinin ne olduğunu tespit etmek amaçlanmıştır. Bu yüzden ilişkisel tarama modeli kullanılımıştır. 


\section{Araştırma Grubu}

Araştırmanın evrenini 2017-2018 eğitim-öğretim yılında Ankara ili Yenimahalle ilçesi MEB'e bağlı okullarda görev yapan 236 beden eğitimi öğretmeni oluşturmaktadır. Örneklemi ise 201 beden eğitimi öğretmeninden oluşmaktadır.

\section{Veri Toplama Araçları}

Öğretmenlerin kişisel ve mesleki bilgilerini içeren bilgi formu kullanılmıştır. Araştırmacı tarafından geliştirilen öğretmenlerin hangi tutumları kullandığının tespiti için İstenmeyen Öğrenci Davranışlarına Karşı Tutum Ölçeği kullanılmıştır. Öğretmenler tarafından en sık kullanılan tutumlar belirlenerek 30 maddelik bir ölçek oluşturulmuştur. $\mathrm{Bu}$ maddelerin güvenirlik ve geçerlik çalışmaları için uzman görüşüne başvurulmuş ve değerlendirmeler sonucunda ise 22 maddeden oluşan bir ölçek elde edilmiştir. Ölçek geçerliği için KMO değeri 0.50'den büyük ve anlamlılık değeri (p) 0.05'den küçük olan veriler geçerliğe uygun olan verilerdir. Yapılan KMO ve Barlett testi ile faktör analizi sonucunda KMO değeri 0.68 , anlamlılık değeri ise 0.05 'ten ( $p=0.000)$ küçük bulunarak ölçeğin geçerli olduğu kanısına varılmıştır. Ölçeğin güvenirliğini belirlemek için Cronbach Alfa iç tutarlılık katsayısı hesaplanmış ve 0.704 olarak bulunmuştur.

Tükenmişlik düzeylerinin belirlenmesi için Ergin (1992)'in geçerlik ve güvenirlik testlerini yaparak Türkçeye uyarladığı Maslach ve Jackson (1981) tarafından geliştirilen Maslach Tükenmişlik Envanteri (MTE) kullanılmıştır. MTE, duygusal tükenme (9 madde), duyarsızlaşma (5 madde) ve kişisel başarısızlık (8 madde) olmak üzere üç alt boyut ve toplam 22 madde içermektedir. Ölçeğin güvenirliği için 552 doktor ve hemşireden elde edilen veriler kullanılmıştır. Cronback Alfa katsayılarına bakıldığında, duygusal tükenme için 0.83 , duyarsızlaşma için 0.71 ve kişisel başarıda olan azalma için 0.72 olduğu görülmektedir. Ölçeğin güvenirliğinin incelenmesi test-tekrar test tekniğiyle de gerçekleştirilmiştir. 5'li likert tipinde yapılandırılmış ölçekte, duygusal tükenme ve duyarsızlaşma alt boyutlarını oluşturan maddeler 0=hiçbir zaman, 1=çok nadir, 2=bazen, 3=çoğu zaman ve 4=her zaman şeklinde puanlanırken kişisel başarı alt boyutunu oluşturan maddeler olumlu ifadeler içerdiği için tersine puanlanarak alt ölçek puanları elde edilmiştir (Ergin, 1992). 


\section{Verilerin Analizi}

Elde edilen veriler bilgisayarda SPSS for Windows 24.0 istatistik programında analiz edilmiştir. İstenmeyen öğrenci davranışlarına karşı tutumlar ve tükenmişlik düzeylerinin cinsiyet, yaş, medeni durum, mesleki kıdem, eğitim durumu, çalışılan okul türü, ders yapılan alan, sınıf mevcudu ve bulunulan okuldaki görev yılı bakımdan anlamlı olarak farklılaşıp farklılaşmadığı incelenmiştir. Verilerin normal dağılım gösterdiği belirlenmiştir. Bu değerlendirmede cinsiyet, medeni durum, eğitim durumu, çalışılan okul türü ve ders yapılan alan için t-testi yapılmış anlamlı farklar için ortalamalar karşılaştırılmıştır. Yaş, mesleki kıdem, sınıf mevcudu ve bulunulan okuldaki görev yılı için tek yönlü varyans analizi yapılarak varyansların homojen olmasından dolayı Tukey testi yapılarak farkların hangi gruplar arasında olduğu 0.05 düzeyinde test edilmiştir. İlişkiyi belirlemek için korelasyon analizi yapılarak öğretmen tutumları ile tükenmişlik alt boyutları arasındaki ilişkinin düzeyine bakılmıştır. Anlamlı ilişki 0.01 düzeyinde test edilmiştir.

\section{Bulgular}

Tablo 1: Beden Eğitimi Öğretmenlerinin Demografik Özellikleri

\begin{tabular}{|c|c|c|c|}
\hline Değişken & Gruplar & $\mathbf{N}$ & $\%$ \\
\hline \multirow{2}{*}{ Cinsiyet } & Kadın & 78 & 38.8 \\
\hline & Erkek & 123 & 61.2 \\
\hline \multirow{5}{*}{ Yaş } & $26-30$ & 19 & 9.5 \\
\hline & $31-35$ & 25 & 12.4 \\
\hline & $36-40$ & 60 & 29.9 \\
\hline & $41-45$ & 51 & 25.4 \\
\hline & 46 ve üstü & 46 & 22.9 \\
\hline \multirow{2}{*}{ Medeni Durum } & Evli & 163 & 81.1 \\
\hline & Bekar & 38 & 18.9 \\
\hline \multirow{5}{*}{ Mesleki Kıdem } & $1-5 \mathrm{yll}$ & 19 & 9.5 \\
\hline & $6-10 \mathrm{yıl}$ & 30 & 14.9 \\
\hline & $11-15 \mathrm{yıl}$ & 46 & 22.9 \\
\hline & $16-20 \mathrm{yll}$ & 57 & 28.4 \\
\hline & 21 yıl ve üstü & 49 & 24.4 \\
\hline \multirow{2}{*}{ Eğitim Durumu } & Lisans & 179 & 89.1 \\
\hline & Yüksek Lisans & 22 & 10.9 \\
\hline \multirow{2}{*}{ Okul Türü } & Ortaokul & 90 & 44.8 \\
\hline & Lise & 111 & 55.2 \\
\hline \multirow{2}{*}{ Ders Yapılan Alan } & Okul Bahçesi & 96 & 47.8 \\
\hline & Spor Salonu & 105 & 52.2 \\
\hline \multirow{4}{*}{ Sınıf Mevcudu } & 20 ve altı & 12 & 6.0 \\
\hline & $21-25$ & 26 & 12.9 \\
\hline & $26-30$ & 87 & 43.3 \\
\hline & 31 ve üstü & 76 & 37.8 \\
\hline \multirow{4}{*}{$\begin{array}{c}\text { Bulunulan Okuldaki } \\
\text { Görev Yılı }\end{array}$} & $1-5$ yıl & 128 & 63.7 \\
\hline & $6-10 \mathrm{yll}$ & 49 & 24.4 \\
\hline & 11-15 yıl & 14 & 7.0 \\
\hline & 16 ve üstü yıl & 10 & 5.0 \\
\hline
\end{tabular}


Tablo 1 incelendiğinde, araştırmaya katılan beden eğitimi öğretmenlerinin; cinsiyetleri 123'ü erkek, 78'i kadın olduğu görülmektedir. 19'u 26-30, 25'i 31-35, 60'। 36-40, 51'i 41-45, 46'sı 46 ve üstü yaşa sahip olduğu görülmektedir. 163'ü evli, 38'ibekarlardan oluştuğu görülmektedir. 19'u 1-5 yıl kıdemi, 30'u 6-10 yıl kıdemi, 46'sı 11-15 yıl kıdemi, 57'si 16-20 yıl kıdemi, 49'u 21 yıl ve üzeri kıdeme sahip olunduğu görülmektedir. 179'u lisans, 22'si yüksek lisans eğitimi alındığı görülmektedir. 90'ırtaokul, 111'i lisede görev yapıldığı görülmektedir. 96'sı okul bahçesinde, 105'i spor salonunda ders yaptığı görülmektedir. 12'si 20 ve altı, 26'sı 21-25, 87'si 26-30, 76'sı 31 ve üstü sınıf mevcudu bulunan sınıflarda ders verildiği görülmektedir. 128'inin 1-5 yıl, 49'unun 6-10 yıl, 14 'ünün 11-15 yıl, 10'unun 16 yıl ve üstü bulundukları okulda okuldaki görev süresine sahip olunduğu görülmektedir.

Tablo 2: Öğretmenlerin İstenmeyen Öğrenci Davranışlarına Karşı Tutumlarının Cinsiyet, Medeni Durum, Eğitim Durumu, Okul Türü Ve Ders Yapılan Alan Değişkenlerine Göre Karşılaştırıması

\begin{tabular}{|c|c|c|c|c|c|c|c|}
\hline Değişken & Gruplar & $\mathbf{N}$ & $\overline{\boldsymbol{X}}$ & S.S. & s.d & $t$ & $\mathbf{p}$ \\
\hline \multirow{2}{*}{ Cinsiyet } & Kadın & 78 & 2.58 & .312 & \multirow[t]{2}{*}{199} & \multirow[t]{2}{*}{1.253} & \multirow[t]{2}{*}{.212} \\
\hline & Erkek & 123 & 2.62 & .320 & & & \\
\hline Medeni & Evli & 163 & 2.61 & .298 & \multirow[t]{2}{*}{199} & \multirow[t]{2}{*}{.696} & \multirow[t]{2}{*}{.487} \\
\hline Durum & Bekar & 38 & 2.57 & .395 & & & \\
\hline Eğitim & Lisans & 179 & 2.59 & .312 & \multirow[t]{2}{*}{199} & \multirow[t]{2}{*}{-1.246} & \multirow[t]{2}{*}{.214} \\
\hline Durumu & Yüksek Lisans & 22 & 2.68 & .359 & & & \\
\hline \multirow{2}{*}{ Okul Türü } & Ortaokul & 90 & 2.63 & .314 & \multirow[t]{2}{*}{199} & \multirow[t]{2}{*}{1.197} & \multirow[t]{2}{*}{.233} \\
\hline & Lise & 111 & 2.57 & .320 & & & \\
\hline Ders Yapılan & Okul Bahçesi & 96 & 2.60 & .335 & \multirow[t]{2}{*}{199} & \multirow[t]{2}{*}{-.151} & \multirow[t]{2}{*}{.880} \\
\hline Alan & Spor Salonu & 105 & 2.60 & .303 & & & \\
\hline
\end{tabular}

Tablo 2'de, istenmeyen davranışlara karşı tutumlar ile değişkenler arasında yapılan t-testi sonucunda ortalamalar arasında anlamlı farklılık olmadığı görülmektedir. 
Tablo 3: Öğretmenlerin İstenmeyen Öğrenci Davranışlarına Karşı Tutumlarının Yaş, Mesleki Kıdem, Sınıf Mevcudu Ve Bulundukları Okuldaki Görev Yılı Değişkenlerine Göre Karşılaştırılması

\begin{tabular}{|c|c|c|c|c|c|c|}
\hline Değişken & Gruplar & $\mathbf{N}$ & s.s. & $\overline{\boldsymbol{X}}$ & p & Farklar \\
\hline \multirow[t]{5}{*}{ Yaş } & $26-30$ yaş & 19 & .358 & 2.60 & \multirow{5}{*}{.043} & \multirow{5}{*}{$\begin{array}{c}\text { *31-35 ile } 46 \text { ve üstü, } \\
\text { *36-40 ile } 46 \text { ve üstü, } \\
\text { *41-45 ile } 46 \text { ve üstü } \\
\text { arasındaki farklar } \\
\text { anlamlı }\end{array}$} \\
\hline & $31-35$ yaş & 25 & .347 & 2.51 & & \\
\hline & $36-40$ yaş & 60 & .308 & 2.57 & & \\
\hline & $41-45$ yaş & 51 & .273 & 2.57 & & \\
\hline & 46 ve üstü yaş & 46 & .322 & 2.72 & & \\
\hline Mesleki & $1-5 \mathrm{yll}$ & 19 & .363 & 2.48 & \multirow{5}{*}{.056} & \multirow{5}{*}{$\begin{array}{c}\text { Gruplar arası anlamlı } \\
\text { fark yok }\end{array}$} \\
\hline \multirow[t]{4}{*}{ Kıdem } & 6-10 yıl & 30 & .362 & 2.66 & & \\
\hline & $11-15$ yıl & 46 & .312 & 2.53 & & \\
\hline & $16-20 \mathrm{yll}$ & 57 & .268 & 2.60 & & \\
\hline & 21 ve üstü yıl & 49 & .313 & 2.68 & & \\
\hline \multirow{4}{*}{$\begin{array}{c}\text { Sınıf } \\
\text { Mevcudu }\end{array}$} & 20 ve altı & 12 & .399 & 2.63 & \multirow{4}{*}{.463} & \multirow{4}{*}{$\begin{array}{c}\text { Gruplar arası anlamlı } \\
\text { fark yok }\end{array}$} \\
\hline & $21-25$ & 26 & .276 & 2.68 & & \\
\hline & $26-30$ & 8 & .307 & 2.57 & & \\
\hline & 31 ve üstü & 76 & .329 & 2.60 & & \\
\hline \multirow{4}{*}{$\begin{array}{c}\text { Bulundukları } \\
\text { Okuldaki } \\
\text { Görev Yılı }\end{array}$} & $1-5 \mathrm{yll}$ & 128 & .302 & 2.57 & \multirow{4}{*}{.014} & \multirow{4}{*}{$\begin{array}{c}\text { *1-5 ile } 16 \text { ve üstü, } \\
\text { *11-15 ile } 16 \text { ve üstü } \\
\text { arasındaki farklar } \\
\text { anlamlı }\end{array}$} \\
\hline & 6-10 yıl & 49 & .342 & 2.64 & & \\
\hline & $11-15 \mathrm{yll}$ & 14 & .280 & 2.49 & & \\
\hline & 16 ve üstü yıl & 10 & .312 & 2.86 & & \\
\hline
\end{tabular}

Tablo 3 incelendiğinde, istenmeyen davranışlara karşı tutumlar ile değişkenler arasında yapılan tek yönlü varyans analizi sonucunda değişkenler arasında anlamlı farklılık olduğu $(p=.043<0.05, p=.014<0.05)$ ve farkın hangi gruplar arasında olduğunu belirlemek için yapılan Tukey analizi sonuçları görülmektedir.

Yaş değişkenine bakıldığında, 31-35 yaş grubundaki öğretmenlerin ortalaması $(\bar{X}=2.51), 46$ ve üstü yaş grubundaki öğretmenlerden $(\bar{X}=2.72)$ daha az, 36-40 yaş grubundaki öğretmenler $(\bar{X}=2.57), 46$ ve üstü yaş grubundaki öğretmenlerden $(\bar{X}=2.72)$ daha az ve $41-45$ yaş grubundaki öğretmenler $(\bar{X}=2.57), 46$ ve üstü yaş grubundaki öğretmenlerden ( $\bar{X}=2.72)$ daha az bu tutumları kullandıkları görülmüştür.

Bulunulan okuldaki görev yılı değişkenine bakıldığında, 1-5 yıl görev yılı grubundaki öğretmenler ( $\bar{X}=2.57), 16$ ve üstü görev yılı grubundaki öğretmenlerden $(\bar{X}=2.86)$ daha az,11-15 görev yılı grubundaki öğretmenler $(\bar{X}=2.49), 16$ ve üstü görev yılı grubundaki öğretmenlerden $(\bar{X}=2.86)$ daha az bu tutumları kullandıkları görülmüştür. 
Tablo 4: Tükenmişlik Alt Boyutlarının Cinsiyet, Medeni Durum, Eğitim Durumu, Okul Türü ve Ders Yapılan Alan Değişkenlerine Göre Karşılaştırılması

\begin{tabular}{|c|c|c|c|c|c|c|c|c|}
\hline Değişken & Alt Boyut & Gruplar & $\mathbf{N}$ & $\overline{\boldsymbol{X}}$ & s.s. & s.d & $\mathbf{t}$ & $\mathbf{p}$ \\
\hline \multirow{6}{*}{ Cinsiyet } & \multirow{2}{*}{$\begin{array}{l}\text { Duygusal } \\
\text { Tükenme }\end{array}$} & Kadın & 78 & 1.73 & .472 & \multirow[t]{2}{*}{199} & \multirow[t]{2}{*}{.611} & \multirow[t]{2}{*}{.542} \\
\hline & & Erkek & 123 & 1.69 & .499 & & & \\
\hline & \multirow{2}{*}{ Duyarsızlık } & Kadın & 78 & 1.40 & .361 & \multirow[t]{2}{*}{199} & \multirow[t]{2}{*}{-.222} & \multirow[t]{2}{*}{.824} \\
\hline & & Erkek & 123 & 1.41 & .461 & & & \\
\hline & \multirow{2}{*}{$\begin{array}{c}\text { Kişisel } \\
\text { Başarısızlık }\end{array}$} & Kadın & 78 & 2.13 & .613 & \multirow[t]{2}{*}{199} & \multirow[t]{2}{*}{1.383} & \multirow[t]{2}{*}{.168} \\
\hline & & Erkek & 123 & 2.02 & .512 & & & \\
\hline \multirow{6}{*}{$\begin{array}{l}\text { Medeni } \\
\text { Durum }\end{array}$} & \multirow{2}{*}{$\begin{array}{l}\text { Duygusal } \\
\text { Tükenme }\end{array}$} & Evli & 163 & 1.69 & .479 & \multirow[t]{2}{*}{199} & \multirow[t]{2}{*}{-.724} & \multirow[t]{2}{*}{.470} \\
\hline & & Bekar & 38 & 1.76 & .527 & & & \\
\hline & \multirow{2}{*}{ Duyarsızlık } & Evli & 163 & 1.39 & .418 & \multirow[t]{2}{*}{199} & \multirow[t]{2}{*}{-.842} & \multirow[t]{2}{*}{.401} \\
\hline & & Bekar & 38 & 1.46 & .448 & & & \\
\hline & \multirow{2}{*}{$\begin{array}{c}\text { Kişisel } \\
\text { Başarısızlık }\end{array}$} & Evli & 163 & 2.07 & .561 & \multirow[t]{2}{*}{199} & \multirow[t]{2}{*}{.235} & \multirow[t]{2}{*}{.815} \\
\hline & & Bekar & 38 & 2.04 & .532 & & & \\
\hline \multirow{6}{*}{$\begin{array}{l}\text { Eğitim } \\
\text { Durumu }\end{array}$} & \multirow{2}{*}{$\begin{array}{l}\text { Duygusal } \\
\text { Tükenme }\end{array}$} & Lisans & 179 & 1.70 & .473 & \multirow[t]{2}{*}{199} & -.315 & .753 \\
\hline & & Yüksek Lisans & 22 & 1.74 & .606 & & & \\
\hline & & Lisans & 179 & 1.41 & .411 & 199 & .340 & .734 \\
\hline & Duyarsızlık & Yüksek Lisans & 22 & 1.38 & .527 & & & \\
\hline & Kişisel & Lisans & 179 & 2.09 & .550 & 199 & 2.002 & .047 \\
\hline & Başarısızlık & Yüksek Lisans & 22 & 1.84 & .554 & & & \\
\hline & Duygusal & Ortaokul & 90 & 1.70 & .527 & 199 & -.170 & .865 \\
\hline & Tükenme & Lise & 111 & 1.71 & .456 & & & \\
\hline Okul & & Ortaokul & 90 & 1.44 & .384 & 199 & .874 & .383 \\
\hline Türü & Duyarsızlık & Lise & 111 & 1.38 & .454 & & & \\
\hline & Kişisel & Ortaokul & 90 & 2.13 & .613 & 199 & 1.434 & .153 \\
\hline & Başarısızlık & Lise & 111 & 2.01 & .499 & & & \\
\hline & Duygusal & Okul Bahçesi & 96 & 1.80 & .492 & 199 & 2.686 & .008 \\
\hline & Tükenme & Spor Salonu & 105 & 1.62 & .469 & & & \\
\hline $\begin{array}{l}\text { Ders } \\
\text { Yanilan }\end{array}$ & & Okul Bahçesi & 96 & 1.45 & .420 & 199 & 1.249 & .213 \\
\hline $\begin{array}{l}\text { Yapilan } \\
\text { Alan }\end{array}$ & Duyarsızlık & Spor Salonu & 105 & 1.37 & .426 & & & \\
\hline & Kişisel & Okul Bahçesi & 96 & 2.19 & .564 & 199 & 3.102 & .002 \\
\hline & Başarısızlık & Spor Salonu & 105 & 1.95 & .523 & & & \\
\hline
\end{tabular}

Tablo 4'te, tükenmişlik alt boyutları ile değişkenler arasında yapılan t-testi sonucu görülmektedir. Eğitim durumu ile kişisel başarısızlık alt boyutu arasında anlamlı farklılık görülmektedir $(p=.047<0.05)$. Lisans yapan öğretmenler $(\bar{X}=2.09)$, yüksek lisans yapan öğretmenlerden $(\bar{X}=1.84)$ daha fazla kişisel başarısızlık yaşamaktadırlar. Ders yapılan alan ile duygusal tükenme ve kişisel başarısızlık alt boyutları arasında anlamlı farklılık görülmektedir $(p=.008<0.05, p=.002<0.05)$. Duygusal tükenme alt boyutunda okul bahçesinde ders yapan öğretmenler $(\overline{\boldsymbol{X}}=1.80)$, spor salonunda ders yapan öğretmenlerden $(\bar{X}=1.62)$ daha fazla duygusal tükendikleri görülmektedir. Kişisel başarısızlık alt boyutunda okul bahçesinde ders yapan öğretmenler $(\bar{X}=2.19)$, spor salonunda ders yapan öğretmenlerden $(\bar{X}=1.95)$ daha fazla kişisel başarısızlık yaşamaktadırlar. 
Tablo 5: Tükenmişlik Alt Boyutlarının Yaş Değişkenine Göre Karşılaştırılması

\begin{tabular}{|c|c|c|c|c|c|c|c|}
\hline Değişken & Alt Boyut & Gruplar & $\mathbf{N}$ & S.S. & $\overline{\bar{X}}$ & p & Farklar \\
\hline \multirow[t]{15}{*}{ Yaş } & Duygusal & $26-30$ yaş & 19 & .465 & 1.59 & .537 & \multirow{5}{*}{$\begin{array}{c}\text { Gruplar arası anlamlı } \\
\text { fark yok }\end{array}$} \\
\hline & \multirow[t]{4}{*}{ Tükenme } & 31-35 yaş & 25 & .538 & 1.84 & & \\
\hline & & 36-40 yaş & 60 & .472 & 1.71 & & \\
\hline & & 41-45 yaş & 51 & .471 & 1.69 & & \\
\hline & & 46 ve üstü yaş & 46 & .512 & 1.69 & & \\
\hline & \multirow[t]{5}{*}{ Duyarsızlaşma } & $26-30$ yaş & 19 & .389 & 1.52 & .341 & \multirow{5}{*}{$\begin{array}{c}\text { Gruplar arası anlaml } \\
\text { fark yok }\end{array}$} \\
\hline & & 31-35 yaş & 25 & .387 & 1.51 & & \\
\hline & & $36-40$ yaş & 60 & .444 & 1.40 & & \\
\hline & & 41-45 yaş & 51 & .456 & 1.40 & & \\
\hline & & 46 ve üstü yaş & 46 & .386 & 1.33 & & \\
\hline & \multirow{5}{*}{$\begin{array}{c}\text { Kişisel } \\
\text { Başarısızlık }\end{array}$} & $26-30$ yaş & 19 & .831 & 2.23 & .004 & \multirow{5}{*}{$\begin{array}{c}\text { 36-40 ile } 46 \text { ve üstü } \\
\text { arasındaki fark } \\
\text { anlamlı }\end{array}$} \\
\hline & & 31-35 yaş & 25 & .438 & 2.15 & & \\
\hline & & 36-40 yaş & 60 & .562 & 2.21 & & \\
\hline & & 41-45 yaş & 51 & .424 & 2.00 & & \\
\hline & & 46 ve üstü yaş & 46 & .519 & 1.83 & & \\
\hline
\end{tabular}

Tablo 5 incelendiğinde, yaş ile tükenmişlik alt boyutları arasında yapılan tek yönlü varyans analizi sonucunda, kişisel başarısızlık alt boyutunda anlamlı farklılıklar ortaya çıkmıştır ( $p=.004<0.05)$. Farkın hangi kıdem gruplarında olduğunu belirlemek için yapılan Tukey analizi sonuçlarına göre, 36-40 yaş grubundaki öğretmenler $(\bar{X}=2.21), 46$ ve üstü yaş grubundaki öğretmenlerden $(\bar{X}=1.83)$ daha fazla kişisel başarısızlık yaşamaktadırlar.

Tablo 6: Tükenmişlik Alt Boyutlarının Mesleki Kıdem Değişkenine Göre Karşılaştırılması

\begin{tabular}{|c|c|c|c|c|c|c|c|}
\hline Değişken & Alt Boyut & Gruplar & $\mathbf{N}$ & s.s. & $\overline{\boldsymbol{X}}$ & p & Farklar \\
\hline \multirow{9}{*}{$\begin{array}{l}\text { Mesleki } \\
\text { Kıdem }\end{array}$} & \multirow{5}{*}{$\begin{array}{l}\text { Duygusal } \\
\text { Tükenme }\end{array}$} & $1-5 \mathrm{yıl}$ & 19 & .412 & 1.66 & \multirow{5}{*}{.935} & \multirow{5}{*}{$\begin{array}{c}\text { Gruplar arası anlamlı } \\
\text { fark yok }\end{array}$} \\
\hline & & 6-10 yıl & 30 & .536 & 1.78 & & \\
\hline & & $11-15 \mathrm{yll}$ & 46 & .543 & 1.69 & & \\
\hline & & $16-20 \mathrm{yll}$ & 57 & .448 & 1.70 & & \\
\hline & & 21 ve üstü yıl & 49 & .490 & 1.70 & & \\
\hline & \multirow{4}{*}{ Duyarsızlık } & $1-5 \mathrm{yll}$ & 19 & .408 & 1.55 & \multirow{4}{*}{.173} & \multirow{4}{*}{$\begin{array}{c}\text { Gruplar arası anlamlı } \\
\text { fark yok }\end{array}$} \\
\hline & & 6-10 yıl & 30 & .491 & 1.52 & & \\
\hline & & $11-15 \mathrm{yll}$ & 46 & .391 & 1.33 & & \\
\hline & & $16-20 \mathrm{yll}$ & 57 & .379 & 1.40 & & \\
\hline
\end{tabular}




\begin{tabular}{|c|c|c|c|c|c|c|}
\hline & 21 ve üstü yıl & 49 & .454 & 1.36 & & \\
\hline \multirow{5}{*}{$\begin{array}{c}\text { Kişisel } \\
\text { Başarısızlık }\end{array}$} & $1-5 \mathrm{yll}$ & 19 & .758 & 2.28 & \multirow{5}{*}{.008} & \multirow{5}{*}{$\begin{array}{l}\text { ^1-5 ile } 21 \text { ve üstü } \\
\text { ^11-15 ile } 21 \text { ve üstü } \\
\text { arasındaki fark anlaml }\end{array}$} \\
\hline & $6-10 \mathrm{yıl}$ & 30 & .520 & 2.09 & & \\
\hline & 11-15 yıl & 46 & .508 & 2.19 & & \\
\hline & 16-20 yıl & 57 & .538 & 2.07 & & \\
\hline & 21 ve üstü yıl & 49 & .486 & 1.84 & & \\
\hline
\end{tabular}

Tablo 6'da tek yönlü varyans analizi sonucuna bakıldığında, mesleki kıdem ile kişisel başarısızlık alt boyutunda anlamlı farklılıklar ortaya çıkmıştır $(p=.008<0.05)$. Farkın hangi kıdem gruplarında olduğunu belirlemek için yapılan Tukey analizi sonuçlarına göre, 1-5 yıla sahip öğretmenler $(\bar{X}=2.28), 21$ ve üstü yıla sahip öğretmenlerden ( $\bar{X}=1.84), 11-15$ yıla sahip öğretmenler $(\bar{X}=2.19), 21$ ve üstü yıla sahip öğretmenlerden ( $\bar{X}=1.84)$ daha fazla kişisel başarısızlık yaşamaktadırlar.

Tablo 7: Tükenmişlik Alt Boyutlarının Sınıf Mevcudu Değişkenine Göre Karşılaştırılması

\begin{tabular}{|c|c|c|c|c|c|c|c|}
\hline & Alt Boyut & Gruplar & $\mathbf{N}$ & S.S. & $\overline{\boldsymbol{X}}$ & $\mathbf{p}$ & Farklar \\
\hline \multirow{12}{*}{$\begin{array}{c}\text { Sınıf } \\
\text { Mevcudu }\end{array}$} & Duygusal & 20 ve altı & 12 & .615 & 1.90 & .085 & \multirow{4}{*}{$\begin{array}{c}\text { Gruplar arası anlamlı } \\
\text { fark yok }\end{array}$} \\
\hline & \multirow[t]{3}{*}{ Tükenme } & $21-25$ & 26 & .468 & 1.64 & & \\
\hline & & $26-30$ & 87 & .439 & 1.63 & & \\
\hline & & 31 ve üstü & 76 & .513 & 1.79 & & \\
\hline & \multirow[t]{4}{*}{ Duyarsızlaşma } & 20 ve altı & 12 & .352 & 1.65 & .230 & \multirow{4}{*}{$\begin{array}{c}\text { Gruplar arası anlamlı } \\
\text { fark yok }\end{array}$} \\
\hline & & $21-25$ & 26 & .396 & 1.36 & & \\
\hline & & $26-30$ & 87 & .447 & 1.40 & & \\
\hline & & 31 ve üstü & 76 & .412 & 1.39 & & \\
\hline & \multirow{4}{*}{$\begin{array}{c}\text { Kişisel } \\
\text { Başarısızlık }\end{array}$} & 20 ve altı & 12 & .691 & 2.32 & \multirow[t]{4}{*}{.018} & *20 ve altı ile 21-25 \\
\hline & & $21-25$ & 26 & .632 & 1.94 & & *20 ve altı ile $26-30$ \\
\hline & & $26-30$ & 87 & .475 & 1.96 & & *26-30 ile 31 ve üstü \\
\hline & & 31 ve üstü & 76 & .563 & 2.18 & & $\begin{array}{c}\text { arasındaki farklar } \\
\text { anlamlı }\end{array}$ \\
\hline
\end{tabular}

Tablo 7'de tek yönlü varyans analizi sonucuna bakıldığında, sınıf mevcudu ile kişisel başarısızlık alt boyutunda anlamlı farklııılar ortaya çıkmıştır $(p=.018<0.05)$. Farkın hangi gruplarda olduğunu belirlemek için yapılan Tukey analizi sonuçlarına göre, 20 ve altı sınıf mevcudunda ders yapan öğretmenler ( $\bar{X}=2.32), 21-25$ sınıf mevcudunda ders yapan öğretmenlerden $(\bar{X}=1.94), 20$ ve altı sınıf mevcudunda ders yapan öğretmenler ( $\bar{X}=2.32), 26-30$ sınıf mevcudunda ders yapan öğretmenlerden 
$(\bar{X}=1.96), 31$ ve üstü sınıf mevcudunda ders yapan öğretmenler $(\bar{X}=2.18), 26-30$ sınıf mevcudunda ders yapan öğretmenlerden $(\bar{X}=1.96)$ daha çok kişisel başarısızlık yaşadıkları görülmektedir.

Tablo 8: Tükenmişlik Alt Boyutlarının Bulunulan Okuldaki Görev Yılı Değişkenine Göre Karşılaştırıması

\begin{tabular}{|c|c|c|c|c|c|c|c|}
\hline & Alt Boyut & Gruplar & $\mathbf{N}$ & S.S. & $\bar{X}$ & $p$ & Farklar \\
\hline \multirow{12}{*}{$\begin{array}{c}\text { Bulunulan } \\
\text { Okuldaki } \\
\text { Görev Yılı }\end{array}$} & \multirow{4}{*}{ Tükenme } & $1-5 \mathrm{yıl}$ & 128 & .526 & 1.66 & .348 & \multirow{4}{*}{$\begin{array}{c}\text { Gruplar arası } \\
\text { anlamlı fark } \\
\text { yok }\end{array}$} \\
\hline & & $6-10 \mathrm{yll}$ & 49 & .411 & 1.78 & & \\
\hline & & $11-15$ yıl & 14 & .403 & 1.69 & & \\
\hline & & 16 ve üstü yıl & 10 & .403 & 1.70 & & \\
\hline & \multirow{4}{*}{ Duyarsızlaşma } & $1-5 \mathrm{yll}$ & 128 & .393 & 1.43 & .522 & \multirow{4}{*}{$\begin{array}{c}\text { Gruplar arası } \\
\text { anlamlı fark } \\
\text { yok }\end{array}$} \\
\hline & & $6-10 \mathrm{yll}$ & 49 & .441 & 1.34 & & \\
\hline & & $11-15$ yıl & 14 & .354 & 1.38 & & \\
\hline & & 16 ve üstü yıl & 10 & .743 & 1.52 & & \\
\hline & \multirow{4}{*}{ Başarısızlık } & $1-5 \mathrm{yll}$ & 128 & .561 & 2.09 & .221 & \multirow{4}{*}{$\begin{array}{c}\text { Gruplar arası } \\
\text { anlamlı fark } \\
\text { yok }\end{array}$} \\
\hline & & $6-10 \mathrm{yıl}$ & 49 & .591 & 2.09 & & \\
\hline & & $11-15 \mathrm{yll}$ & 14 & .562 & 1.94 & & \\
\hline & & 16 ve üstü yıl & 10 & .554 & 1.75 & & \\
\hline
\end{tabular}

Tablo 8'de tükenmişlik alt boyutları ile değişkenler arasında yapılan tek yönlü varyans analizi sonucunda ortalamalar arasında anlamlı farklılık görülmemektedir.

Tablo 9: İstenmeyen Öğrenci Davranışlarına Karşı Öğretmen Tutumları ve Tükenmişlik

\begin{tabular}{ccccc}
\hline & & $\begin{array}{c}\text { Duygusal } \\
\text { tükenme }\end{array}$ & Duyarsızlaşma & $\begin{array}{c}\text { Kişisel } \\
\text { Başarısızlık }\end{array}$ \\
\hline $\begin{array}{c}\text { İstenmeyen } \\
\begin{array}{c}\text { Öğrenci } \\
\text { Davranışlarına } \\
\text { Karşı Tutumlar }\end{array}\end{array}$ & $\begin{array}{c}\text { Pearson } \\
\text { Korelasyon }(r)\end{array}$ & .171 & .102 & $-.256^{\star *}$ \\
\cline { 2 - 5 } & Sig. (2-tailed) $(p)$ & .015 & .148 & .000 \\
\hline
\end{tabular}

Tablo 9'da İstenmeyen davranışlarına karşı tutumlar ile tükenmişlik düzeyleri Arasındaki İlişkiyi Gösteren Korelasyon sonucunda aralarındaki ilişkinin anlamlı olduğu ve korelasyon puanının ise $-0.25(p=.000<0.01)$ olduğu görülmektedir.

Araştırmada korelasyon aralıklarının yorumlamasında; $0,70-1,00$ aralığı yüksek; $0,70-0,30$ aralığı orta ve $0,30-0,00$ aralığı ise düşük düzey olduğu dikkate 
alınmıştır (Yıldırım, 2016). Verilere bakıldığında istenmeyen davranışlara karşı tutumlar ile kişisel başarısızlık arasındaki ilişkinin düşük ve negatif olduğu görülmektedir.

\section{Tartışma ve Sonuç}

Araştırmamızda istenmeyen öğrenci davranışlarına karşı öğretmen tutumlarının değişkenler bakımından incelenmesiyle elde edilen bulgulara bakıldığında; cinsiyete göre anlamlı farklııı bulunmamıştır. Literatüre bakıldığında Sakallığlu (2014)'nun çalışması araştırmamızla benzerlik göstermektedir. Araştırmamızın sonuçlarında, medeni durum, mesleki kıdem, eğitim durumu, ders yapılan alana bakıldığında yine anlamlı fark bulunmamışıı. Sakallıŏlu (2014) da yaptığı çalışmasında mesleki kıdem ve sınıf mevcudu değişkenleri ile istenmeyen davranışlara olan tutumlar arasında anlamlı fark bulamamıştır. Yaşa göre; 31-35 ile 46 ve üstü, 36-40 ile 46 ve üstü, $41-45$ ile 46 ve üstü grupları arasında anlamlı fark bulunmuştur. Son olarak öğretmenlerin bulundukları okuldaki görev yılına göre 1-5 yıl ile 16 ve üstü yıl ve 11-15 yıl ile 16 ve üstü yıl görev yılı grupları arasında anlamlı fark bulunmuştur. Öğretmenlerin bulundukları okuldaki görev yılları ve yaşları artıkça istenmeyen davranışlara karşı tutumları daha fazla kullandıkları görülmektedir.

Öğretmenlerin tükenmişlik düzeylerinin değişkenler bakımından incelenmesiyle elde edilen bulgulara bakıldığında; cinsiyete göre anlamlı fark bulunmamıştır. Literatüre bakıldığında benzer çalışmaların olduğu görülmektedir. Yılmaz (2013), Gögercin (2017), Yıldırım (2016), Koralay (2014)'ın tükenmişlik düzeylerini konu aldıkları çalışmalarında tükenmişlik ile cinsiyet arasında anlamlı fark bulamamışlardır. Yaş değişkenine göre sadece kişisel başarısızlık alt boyutunda 3640 yaşa sahip öğretmenler, 46 ve üstü yaşa sahip öğretmenlerden daha yüksek puan alarak anlamlı olarak farklılaşmıştır. 36-40 yaşa sahip öğretmenlerin daha fazla tükenmişlik yaşaması az tecrübelerinin olmasından kaynaklanıyor olabilir. Araştırmamıza benzerlik gösteren Çintiriz (2016) tarafından yapılan çalışmada 31-40 yaşa sahip öğretmenlerin kişisel başarısızlık puanları 41-50 ile 51 ve üstü yaşa sahip öğretmenlerden yüksek çıkarak yaş azaldıkça kişisel başarısızlık hissinin arttığı görülmektedir.

Tükenmişlik düzeylerinin medeni durum açısından incelenmesi sonucunda anlamlı farklılık bulunamamıştır. Yılmaz (2013) ve Çintiriz (2016)'in öğretmenlerin tükenmişlik düzeyleriyle ilgili yaptıkları çalışmalarda da anlamlı farkııı̆a 
rastlanmamıştır. Tükenmişliğin mesleki kıdem açısından incelenmesinde, 1-5 yıl kıdem ile 21 ve üstü kıdem, 11-15 yıl kıdem ile 21 ve üstü kıdem grupları arasında anlamlı farklar bulunmuştur. Mesleki kıdem azaldıkça kişisel başarı hissinde artma görülmüştür. Tuna (2010) da mesleki kıdem ile kişisel başarısızlık alt boyutu arasında anlamlı fark bulmuştur. 6-10 yıl kıdeme sahip öğretmenlerin üst kıdem gruplarına göre daha fazla tükendiğini ortaya koymuştur.

Duyarsızlaşma ve kişisel başarısızlık alt boyutları ile eğitim durumu arasında anlamlı farklar bulunmuştur. Lisans mezunu öğretmenler yüksek lisans mezunu olanlardan daha fazla tükendiği ortaya konmuştur. Okul türü değişkenine bakıldığında tükenmişlik alt boyutları arasında anlamlı farklar bulunmadığı görülmektedir. Gögercin (2017)tükenmişlik düzeylerine ilişkin yaptığı çalışmasında da anlamlı farklar bulunmamıştır.

Duygusal tükenme ve kişisel başarısızlık alt boyutları ile öğretmenlerin ders yaptıkları alana bakıldığında anlamlı farklar ortaya çıkmıştır. Okul bahçesinde ders yapan öğretmenlerin daha fazla tükendiği ortaya çıkmıştır. Bu durumun bazı okullardaki spor salonu olmamasından dolayı materyal eksikliği ve ders veriminin düşmesi ile alakalı olduğunu söyleyebiliriz. Sınıf mevcuduna bakıldığında kişisel başarısızık alt boyutunda 20 ve altı mevcudu olan öğretmenler, 21-25 ve 26-30 mevcudu olan öğretmenlerden daha yüksek puan alarak ve 26- 30 mevcudu olan öğretmenler, 31 ve üstü mevcudu olan öğretmenlerden daha düşük puan alarak anlamlı olarak farklılaşmıştır. 20 ve altı mevduda sahip öğretmenlerin 21-25 ve 26-30 mevcuda sahip öğretmenlerden daha fazla kişisel başarısızlık yaşaması daha az öğrenciye fayda sağladığını düşünmesinden kaynaklanıyor, 31 ve üstü mevcuda sahip öğretmenlerin 26-30 mevcuda sahip öğretmenlerden daha fazla kişisel başarısızlık yaşaması sınıfın kalabalık olmasından kaynaklı olarak öğretmenlerin, her öğrenciye yeterli bilgi verememesini düşünmelerinden kaynaklanıyor olabilir. Son olarak öğretmenlerin bulundukları okuldaki görev yılı ile tükenmişlik alt boyutları arasında anlamlı farklar bulunamamıştır.

İstenmeyen öğrenci davranışlarına karşı öğretmen tutumları ile tükenmişliğin alt boyutları arasındaki ilişkiyi anlamak için yapılan Pearson Korelasyonu'na ilişkin bulgulara bakıldığında sadece kişisel başarısızlık $(p=.00 .<0.01)$ ile istenmeyen davranışlara karşı tutumlar arasındaki ilişkinin anlamlı düzeyde olduğu görülmektedir. Araştırmamızda korelasyon değer aralıkları; 0,70- 1,00 aralığı yüksek; 0,70-0,30 aralığı orta ve $0,30-0,00$ aralığı ise düşük düzey olduğu dikkate alınarak 
yorumlanmıştır (Yıldııım, 2016). Sonuç olarak istenmeyen davranışlara karşı öğretmen tutumları ile kişisel başarısızık alt boyutu arasındaki ilişki -0.25 olarak düşük ve negatif düzeyde bulunmuştur.

\section{Kaynakça}

Başar, H. (2001). Sınıf Yönetimi. 5. Baskı, Ankara: Pegem A Yayıncılık, s:165.

Cemaloğlu, N. (2015). Disiplin İle Illgili Kavramlar, İlkeler ve Uygulamalar. Millî Eğitim, 7(14): 44-73.

Cordes, C., Dougherty, T. (1993). A Rewiewand an İntegration of Research on Job Burnout. Academy of Management Review, 18(4): 621-656.

Çintiriz, Ş. (2016). Mesleki ve teknik Anadolu liselerinde kültür dersi öğretmenlerinin mesleki tükenmişlik düzeyinin tespiti, Yüksek Lisans Tezi, İstanbul Aydın Üniversitesi Sosyal Bilimler Enstitüsü, İstanbul.

Dolye, W. (1986). Handbook of Research on Taeching, Classroom Organisation and Management. Ed: M. C. Wittrock, 3. Edition, New York: Macmillan Pub. Comp, s:419.

Erden, M. (2008). Sınıf Yönetimi. Ankara: Arkadaş Yayınevi, s:15.

Ergin, C. (1992). Doktor ve Hemşirelerde Tükenmişlik ve Maslach Tükenmişlik Envanterinin Uygulanması. 7. Ulusal Psikoloji Kongresi Bilimsel Çalışmaları El Kitabı. Ankara: Psikologlar Derneği Yayınları, s:143-154.

Freudenberger, H. J. (1981). Burnout: How to Beat the High Cost of Success, New York: Bantam Books, s:330.

Gögercin, T. (2017). Beden eğitimi öğretmenlerinin iş tatmini ve mesleki tükenmişlik düzeylerinin incelenmesi, Yüksek Lisans Tezi, İstanbul Gelişim Üniversitesi Sağlık Bilimleri Enstitüsü, İstanbul.

Hock, R. R. (1988). Public Personal Management, Professional Burnout Among Public School Teachers, 17(2): 231-233.

Koralay, F. D. (2014). Illkokullarda görev yapan öğretmenlerin mesleki tükenmişlik düzeyleri, Yüksek Lisans Tezi, Dokuz Eylül Üniversitesi Eğitim Bilimleri Enstitüsü, İzmir.

Korkmaz, İ. (2011). İstenmeyen Davranışların Önlenmesi. Sınıf Yönetimi. Ed: Z. Kaya, 12. Baskı, Ankara: Pegem Akademi, s:7.

Kyriacou, C. (1987). Teacher Stress and Burnout: An International Review. Educational Research, 29(2): 146-152. 
Maslach, C.,Susan, J. (1981). The Measurement of Experienced Burnout. Journal of Occupational Behaviour, 2: 99-113.

Maslach, C., Schaufeli, W. B., Leiter, M. P. (2001). Job Burnout. Annual Reviews Psychology, 52: 397-422.

Okutan, M. (2015). Sınıf Yönetiminde Örnek Olaylar. 5.Baskı, Ankara: Pegem Akademi, s:7.

Özdemir, T. (2009). İstenmeyen öğrenci davranışlarının görülme sıklığı ile öğretmenlerin tükenmişlik düzeyleri arasındaki ilişki, Doktora Tezi, Abant izzet Baysal Üniversitesi Sosyal Bilimler Enstitüsü, Bolu.

Özdemir, I. E. (2011). Sınıf ortamında İstenmeyen Davranışlar ve Yönetimi. Sınıf Yönetimi. Ed: M. Çağatay Özdemir, 2.Baskı, Ankara: Pegem A Akademi, s:85.

Özmen, H. (2001). Görme engelliler okullarında görev yapan öğretmenlerin tükenmişlik düzeyleri, Yüksek Lisans Tezi, Gazi Üniversitesi Eğitim Bilimleri Enstitüsü, Ankara.

Özyürek, M. (2013). Olumlu Sınıf Yönetimi.4.Baskı, Ankara: Kök Yayıncııı, s:16.

Sakallıoğlu, A. (2014). Ortaokullarda görev yapan branş öğretmenlerinin sınıf içerisinde karşılaşıtıları istenmeyen davranışlar ve bunları yönetmede kullandıkları stratejiler, Yüksek Lisans Tezi. Okan Üniversitesi Sosyal Bilimler Enstitüsü, İstanbul.

Sarıtaş, M. (2000). Sınıf Yönetimi ve Disiplinle İlgili Kurallar Geliştirme ve Uygulama, Sınıf Yönetiminde Yeni Yaklaşımlar. Ed: L. Küçükahmet, Ankara: Nobel Yayıncılık, s:79.

Tuna, M. (2010).Beden eğitimi öğretmenlerinin tükenmişlik düzeyleri (Ankara ili örneği), Yüksek Lisans Tezi, Gazi Üniversitesi Sağlık Bilimleri Enstitüsü, Ankara.

Tümkaya, S. (1996). Öğretmenlerdeki tükenmişlik, görülen psikolojik belirtiler ve başa çıkma davranışları, Çukurova Üniversitesi Sosyal Bilimler Enstitüsü, Adana.

Weston, R. (1997). Deling with Discipline Problems. Health Education, s:9-10.

Yalçınkaya, M., Küçükkaragöz, H. (2006). Sınıf Yönetimi Yaklaşımları. Sınıf Yönetimi. Ed: M. Yılman, 1.Basım, İzmir: Nobel Yayın, s:128.

Yıldııım, U. (2016). Sınıf öğretmenlerinin tükenmişlik düzeyi ile sınıf yönetimi arasındaki ilişki, Yüksek Lisans Tezi, İstanbul Aydın Üniversitesi Sosyal bilimler Enstitüsü, İstanbul. 